\title{
A Review of Marketing Mix: 4Ps or More?
}

\author{
Chai Lee Goi \\ Department of Marketing \& Management, School of Business, Curtin University of Technology \\ CDT 250, 98009 Miri, Sarawak, Malaysia \\ Tel: 60-85-443-939Ｅ-mail: goi.chai.lee@curtin.edu.my
}

\begin{abstract}
The main objective of this study is to review the present marketing mix applies particularly to the marketing. This study provides an idea to the marketers and can be used as tools to assist them in pursuing their marketing objectives. Borden (1965) claims to be the first to have used the term marketing mix and that it was suggested to him by Culliton's (1948). McCarthy (1964) offered marketing mix, often referred to as the 4Ps, as a means of translating marketing planning into practice (Bennett, 1997). Marketing mix is originating from the single P (price) of microeconomic theory (Chong, 2003). New Ps were introduced into the marketing scene in order to face up into a highly competitively charged environment (Low and Tan, 1995). Even, Möller (2006) presents an up-to-date picture of the current standing in the debate around the Mix as marketing paradigm and predominant marketing management tool by reviewing academic views from five marketing management sub-disciplines (consumer marketing, relationship marketing, services marketing, retail marketing and industrial marketing) and an emerging marketing (E-Commerce). The concept of 4Ps has been criticised by number of studies, examples Lauterborn (1990), Möller (2006), Popovic (2006) and Fakeideas (2008). However, in spite of its deficiencies, the 4Ps remain a staple of the marketing mix. The subsequent Ps have yet to overcome a consensus about eligibility and agreement over the practical application (Kent and Brown, 2006).
\end{abstract}

Keywords: Marketing mix, $P$

\section{Introduction}

Marketing mix is originating from the single P (price) of microeconomic theory (Chong, 2003). McCarthy (1964) offered the "marketing mix", often referred to as the "4Ps", as a means of translating marketing planning into practice (Bennett, 1997). Marketing mix is not a scientific theory, but merely a conceptual framework that identifies thee principal decision making managers make in configuring their offerings to suit consumers' needs. The tools can be used to develop both long-term strategies and short-term tactical programmes (Palmer, 2004). The idea of the marketing mix is the same idea as when mixing a cake. A baker will alter the proportions of ingredients in a cake depending on the type of cake we wishes to bake. The proportions in the marketing mix can be altered in the same way and differ from the product to product (Hodder Education, n.d). The marketing mix management paradigm has dominated marketing thought, research and practice (Grönroos, 1994), and "as a creator of differentiation" (Van Waterschoot, n.d) since it was introduced in 1940s. Kent (1986) refers to the 4Ps of the marketing mix as "the holy quadruple...of the marketing faith...written in tablets of stone". Marketing mix has been extremely influential in informing the development of both marketing theory and practise (Möller, 2006).

The main reasons the marketing mix is a powerful concept are It makes marketing seem easy to handle, allows the separation of marketing from other activities of the firm and the delegation of marketing tasks to specialists; and - The components of the marketing mix can change a firm's competitive position (Grönroos, 1994). The marketing mix concept also has two important benefits. First, it is an important tool used to enable one to see that the marketing manager's job is, in a large part, a matter of trading off the benefits of one's competitive strengths in the marketing mix against the benefits of others. The second benefit of the marketing mix is that it helps to reveal another dimension of the marketing manager's job. All managers have to allocate available resources among various demands, and the marketing manager will in turn allocate these available resources among the various competitive devices of the marketing mix. In doing so, this will help to instil the marketing philosophy in the organisation (Low and Tan, 1995).

However, Möller (2006) highlighted that the shortcomings of the 4Ps marketing mix framework, as the pillars of the traditional marketing management have frequently become the target of intense criticism. A number of critics even go as far as rejecting the 4Ps altogether, proposing alternative frameworks (see Table 1-6). 


\section{Objective}

Since its introduction, developments on the commercial landscape and changes in consumer and organisational attitudes over the last few decades (1940s - 2000s) have frequently prompted marketing thinkers to explore new theoretical approaches and expanding the scope of the marketing mix concept. Number of researchers (eg. Grönroos, 1994; Constantinides, 2002; Goi, 2005; Möller, 2006) explores more 'P's instead of traditional 4Ps only currently applied in the market. However, the creation of new 'P' seem like unstop. New Ps were introduced into the marketing scene in order to face up into a highly competitively charged environment (Low and Tan, 1995). Thus, the main objective of this study is to review the present marketing mix applies particularly to the marketing.

\section{History and Implementation of Marketing Mix}

Borden (1965) claims to be the first to have used the term "marketing mix" and that it was suggested to him by Culliton's (1948) description of a business executive as "mixer of ingredients". An executive is "a mixer of ingredients, who sometimes follows a recipe as he goes along, sometimes adapts a recipe to the ingredients immediately available, and sometimes experiments with or invents ingredients no one else has tried" (Culliton, 1948).

The early marketing concept in a similar way to the notion of the marketing mix, based on the idea of action parameters presented in 1930s by Stackelberg (1939). Rasmussen (1955) then developed what became known as parameter theory. He proposes that the four determinants of competition and sales are price, quality, service and advertising. Mickwitz (1959) applies this theory to the Product Life Cycle Concept.

Borden's original marketing mix had a set of 12 elements namely: product planning; pricing; branding; channels of distribution; personal selling; advertising; promotions; packaging; display; servicing; physical handling; and fact finding and analysis. Frey (1961) suggests that marketing variables should be divided into two parts: the offering (product, packaging, brand, price and service) and the methods and tools (distribution channels, personal selling, advertising, sales promotion and publicity). On the other hand, Lazer and Kelly (1962) and Lazer, Culley and Staudt (1973) suggested three elements of marketing mix: the goods and services mix, the distribution mix and the communication mix. McCarthy (1964) refined Borden's (1965) idea further and defined the marketing mix as a combination of all of the factors at a marketing manger's command to satisfy the target market. He regrouped Borden's 12 elements to four elements or 4Ps, namely product, price, promotion and place at a marketing manger's command to satisfy the target market.

Especially in 1980s onward, number of researchers proposes new 'P' into the marketing mix. Judd (1987) proposes a fifth P (people). Booms and Bitner (1980) add 3 Ps (participants, physical evidence and process) to the original 4 Ps to apply the marketing mix concept to service. Kotler (1986) adds political power and public opinion formation to the Ps concept. Baumgartner (1991) suggests the concept of 15 Ps. MaGrath (1986) suggests the addition of 3 Ps (personnel, physical facilities and process management). Vignalis and Davis (1994) suggests the addition of S (service) to the marketing mix. Goldsmith (1999) suggests that there should be 8 Ps (product, price, place, promotion, participants, physical evidence, process and personalisation).

Möller (2006) presents an up-to-date picture of the current standing in the debate around the Mix as marketing paradigm and predominant marketing management tool by reviewing academic views from five marketing management sub-disciplines (consumer marketing, relationship marketing, services marketing, retail marketing and industrial marketing) and an emerging marketing (E-Commerce) (Table 1-6). Most of researchers and writers reviewed in these domains express serious doubts as to the role of the Mix as marketing management tool in its original form, proposing alternative approaches, which is adding new parameters to the original Mix or replacing it with alternative frameworks altogether.

\section{Criticise on Marketing Mix}

4Ps delimits four distinct, well-defined and independent management processes. Despite the consistent effort by many physical businesses to deal with the $4 \mathrm{P}$ in an integrated manner, the drafting but mainly the implementation of the $\mathrm{P}$ policies remains largely the task of various departments and persons within the organisation. Even more significant thought is the fact that the customer is typically experiencing the individual effects of each of the 4Ps in diverse occasions, times and places, even in case that some companies take great pains to fully integrate their marketing activities internally (Constantinides, 2002; Wang, Wang and Yao, 2005). However, a study by Rafiq and Ahmed (1995) suggested that there is a high degree of dissatisfaction with the 4Ps framework. Even, Overall these results provide fairly strong support Booms and Bitner's (1981) 7P framework should replace McCarthy's 4Ps framework as the generic marketing mix. Development of marketing mix has received considerable academic and industry attention. Numerous modifications to the 4Ps framework have been proposed, the most concerted criticism has come from the services marketing area (Rafiq and Ahmed, 1995).

The introductory marketing texts suggest that all parts of the marketing mix (4Ps) are equally important, since a deficiency in any one can mean failure (Kellerman, Gordon and Hekmat, 1995). Number of studies of industrial 
marketers and purchasers indicated that the marketing mix components differ significantly in importance (Jackson, Burdick and Keith, 1985). Two surveys focused on determination of key marketing policies and procedures common to successful manufacturing firms (Jackson, Burdick and Keith, 1985). Udell (1964) determined that these key policies and procedures included those related to product efforts and sales efforts. This followed in order by promotion, price, and place. In a replication of this survey, Robicheaux (1976) found that key marketing policies had changed significantly. Pricing was considered the most important marketing activity in Robicheaux's (1976) survey, although it ranked only sixth in Udell's (1964) survey. Udell (1968) found that sales efforts were rated as most important, followed by product efforts, pricing, and distribution. LaLonde (1977) found product related criteria to be most important, followed by distribution, price, and promotion. Perreault and Russ (1976) found that product quality was considered most important, followed by distribution service and price. McDaniel and Hise, (1984) found that chief executive officers judge two of the 4 Ps, pricing and product to be somewhat more important than the other two - place (physical distribution) and promotion. Kurtz and Boone (1987) found that on the average, business persons ranked the 4 Ps to be of most importance in the following order: price, product, distribution, and promotion. Thus, it appears from these studies that business executives do not really view the 4 Ps as being equally important, but consider the price and product components to be the most important (Kellerman, Gordon and Hekmat, 1995).

The concept of 4Ps has been criticised as being a production-oriented definition of marketing, and not a customer-oriented (Popovic, 2006). It's referred to as a marketing management perspective. Lauterborn (1990) claims that each of these variables should also be seen from a consumer's perspective. This transformation is accomplished by converting product into customer solution, price into cost to the customer, place into convenience, and promotion into communication, or the 4C's. Möller (2006) highlighted 3-4 key criticisms against the Marketing Mix framework:

- $\quad$ The Mix does not consider customer behaviour but is internally oriented.

- The Mix regards customers as passive; it does not allow interaction and cannot capture relationships.

- The Mix is void of theoretical content; it works primarily as a simplistic device focusing the attention of management.

- $\quad$ The Mix does not offer help for personification of marketing activities.

A review of another article, "Revision: Reviewing the Marketing Mix" (Fakeideas, 2008) found that:

- $\quad$ The mix does not take into consideration the unique elements of services marketing.

- Product is stated in the singular but most companies do not sell a product in isolation. Marketers sell product lines, or brands, all interconnected in the mind of the consumer

- The mix does not mention relationship building which has become a major marketing focus, or the experiences that consumers buy.

- The conceptualisation of the mix has implied marketers are the central element. This is not the case. Marketing is meant to be 'customer-focused management'.

Even, a study by Rafiq and Ahmed (1995) found that there is a high degree of dissatisfaction with the 4Ps, however, 4Ps is thought to be most relevant for introductory marketing and consumer marketing. The result also suggests that the 7Ps framework has already achieved a high degree of acceptance as a generic marketing mix among our sample of respondents. Rafiq and Ahmed (1995) also highlighted the strengths and weaknesses of the 4Ps and 7Ps mixes (Table 7).

\section{Conclusion}

Marketing mix management paradigm has dominated marketing since 1940s and McCarthy (1964) further developed this idea and refined the principle to what is generally known today as the 4Ps. However, in the post dot-com boom, marketing managers are learning to cope with a whole host of new marketing elements that have emerged from the online world of the Internet. In some ways these new marketing elements have close analogs in the offline world, and yet from another perspective they are revolutionary and worthy of a new characterisation into the E-Marketing mix (or the e-marketing delta to the traditional marketing mix) (Kalyanam and McIntyre, 2002).

Marketing mix used by a particular firm will vary according to its resources, market conditions and changing needs of clients. The importance of some elements within the marketing mix will vary at any one point in time. Decisions cannot be made on one element of the marketing mix without considering its impact on other elements (Low and Kok, 1997). As McCarthy (1960) pointed out that "the number of possible strategies of the marketing mix is infinite.

Even number of criticisms on 4Ps, however, it has been extremely influential in informing the development of both marketing theory and practise. There is also too little reflection on the theoretical foundations of the normative advice found in abundance in the text books (Möller, 2006). Marketing mix was particularly useful in the early days of the marketing concept when physical products represented a larger portion of the economy. Today, with marketing more 
integrated into organisations and with a wider variety of products and markets, some authors have attempted to extend its usefulness by proposing a fifth $\mathrm{P}$, such as packaging, people and process. Today however, the marketing mix most commonly remains based on the 4 P's. Despite its limitations and perhaps because of its simplicity, the use of this framework remains strong and many marketing textbooks have been organised around it (NetMBA, n.d). In spite of its deficiencies, the 4Ps remain a staple of the marketing mix (Kent and Brown, 2006).

\section{References}

Aldridge, A., Forcht, K. \& Pierson, J. (1997). Get Linked or Get Lost: Marketing Strategy for the Internet. Internet Research: Electronic Networking Applications and Policy, 7(3), 161-169.

Allen, E. \& Fjermestad, J. (2001). E-Commerce Marketing Strategies: An Integrated Framework and Case Analysis. Logistics Information Management, 14(1/2), 14-23.

Andersen, J. C. \& Narus J. A. (1999). Business Market Management, Understanding, Creating and Delivering Value. New Jersey. Prentice Hall.

Baungartner J. (1991). Nonmarketing Professionals Need More Than 4Ps, Marketing News.

Beckwith, H. (2001). The Invisible Touch - The Four Keys of Modern Marketing. Texere Publishing.

Bennett, A. R. (1997). The Five Vs - A Buyer's Perspective of the Marketing Mix. Marketing Intelligence \& Planning, 15(3), 151-156.

Bhatt G. \& Emdad, A. F. (2001). An Analysis of the Virtual Chain in Electronic Commerce. Logistics Information Management, 14(1/2), 78-85.

Boekema, J. J., Bueren Van, E. B, Lobstein, S., Oosterhuis, A. \& Schweitzer, P. (1995). Basisboek Marketing (Basic Book of Marketing), NL: Derde druk, Groningen, Wolters-Noordhoff.

Booms B. H. \& Bitner B. J. (1980). Marketing strategies and organisation structures for service firms. In Donnelly, J. \& George W. R. (Eds.), Marketing of services. American Marketing Association, 47-51.

Borden, N. H. (1965). The concept of the marketing mix. In Schwartz, G. (Ed), Science in marketing. New York: John Wiley \& Sons, 386-397.

Brunner, G. C. (1989). The Marketing Mix: Time for Reconceptualization. Journal of Marketing Education, 11, 72-77.

Chaffey, D., Mayer, R., Johnston, K. \& Ellis-Chadwick, F. (2000). Internet Marketing, Strategy, Implementation and Practice. FT/Prentice Hall, 40-48, 151-168.

Chong, K. W. (2003). The Role of Pricing in Relationship Marketing - A Study of the Singapore Heavy Equipment Spare Parts Industry, PhD Dissertation, International Graduate School of Management, University of South Australia.

Constantinides, E. (2002). The 4S Web-Marketing Mix Model. Electronic Commerce Research and Applications, 1(1), 57-76.

Cowell, D. W. (1984). The Marketing of Services, Institute of Marketing and the CAM foundation. Heineman Professional Publishing.

Culliton, J.W. (1948). The Management of Marketing Costs. Division of Research, Graduate School of Business Administration, Boston, MA: Harvard University.

Davis W. \& Brush, K. E. (1997). High-Tech Industry Marketing: The Elements of a Sophisticated Global Strategy. Industrial Marketing Management, 26(1), 1-13.

Doyle, P. (1994). Marketing Management and Strategy. Prentice Hall.

English, J. (2000). The Four "P"s of Marketing are Dead. Marketing Health Services, 20(2), 20-23.

Evans, J. R. \& King, V. E. (1999). Business-to-Business Marketing and the World Wide Web: Planning, Managing and Assessing Web Sites. Industrial Marketing Management, 28(4), 343-358.

Fakeideas. (2008). Revision: Reviewing the Marketing Mix. [Online] Available: http://fakeideas.co.uk/2008/03/07/revision-reviewing-the-marketing-mix.

Frey, A. W. (1961). Advertising (3rd ed.). New York: The Ronald Press.

Fryar, C. R. (1991). What's Different About Services Marketing?. The Journal of Marketing Services, 5(4), 53-58.

Goi, C. L. (2005). Marketing Mix: A Review of 'P'. Journal of Internet Banking and Commence, 10.

Goldsmith R. E. (1999). The Personalised Marketplace: Beyond the 4Ps. Marketing Intelligence and Planning, 17(4), 178-185.

Grönroos, C. (1994). From Marketing Mix to Relationship Marketing: Towards A Paradigm Shift in Marketing. 
Management Decision, 32(2), 4-20.

Grove, S.J., Fisk, R.P. \& John, J. (2000). Service as Theater, Guidelines and Implications, Handbook Services Marketing and Management. Sage Publications Inc, 25.

Gummesson, E. (1994). Making Relationship Marketing Operational. International Journal of Service Industry Management, 5(5), 5-20.

Gummesson, E. (1997). Relationship Marketing as a Paradigm Shift: Some Conclusions From the 30R Approach. Management Decision, 35(4), 267-272.

Healy, M., Hastings, K., Brown, L. \& Gardiner, M. (2001). The Old, The New and the Complicated - A Trilogy of Marketing Relationships. European Journal of Marketing, 35(1/2), 182-193.

Heuvel, J. (1993). Diensten Marketing (Services marketing). The Netherlands Wolters-Noordhoff Groningen.

Hodder Education (n.d). Introduction to the Marketing Mix - Pricing. [Online] Available: http://www.hoddersamplepages.co.uk/pdfs/cceabus6.pdf.

Jackson, D. W. Jr., Burdick, R. K. \& Keith, J. E. (1985). Purchasing Agents' Perceived Importance of Marketing Mix Components in Different Industrial Purchase Situations. Journal of Business Research, 13, 361-373.

Judd V. C. (1987). Differentiate With the 5th P: People. Industrial Marketing Management, 16(4), 241-247.

Kalyanam, K. \& McIntyre, S. (2002). The E-Marketing Mix: A Contribution of the E-Tailing Wars. Working Paper, Leavey School of Business, Santa Clara University. [Online] Available: http://lsb.scu.edu/faculty/research/working_papers/pdf/e-marketing.pdf.

Kambil, A. \& Nunes, P. (2000). Internet Marketing: Lessons from the Field, Research Note. Accenture Institute for Strategic Change. [Online] Available: http://www.accenture.com/xd/xd.asp?it=enweb\&xd=_isc/iscresearchnote_12.xml (Retrieved from July 14 2000).

Kellerman, B. J., Gordon, P. J. \& Hekmat, F. (1995). Product and Pricing Courses are Underrepresented in Undergraduate Marketing Curricula. Journal of Product \& Brand Management, 4(1), 18-25.

Kent, R. A. (1986). Faith in the four Ps: An alternative. Journal of Marketing Management, 2, 145-154.

Kent, T. \& Brown, R. B. (2006). Erotic Retailing in the UK (1963-2003) - The View from the Marketing Mix. Journal of Management History, 12(2), 199-211.

Kotler, P. (1984). Marketing Management: Analysis, Planning and Control (5th ed.). New Jersey: Prentice-Hall.

Kotler, P. (1986). Principles of Marketing (3rd ed.). New Jersey: Prentice Hall.

Kotler, P. (2003). Marketing Management (11th ed.). Prentice Hall International Editions.

Kurtz, D. L. \& Boone, L. E. (1987). Marketing (3rd ed.). Chicago The Dryden Press.

LaLonde, B. (1977). Distribution Logistics Grows in Importance for Marketers, But Faculty Acceptance Lags. Marketing News, 29, 4.

Lauterborn, B. (1990). New Marketing Litany: Four Ps Passé: C-Words Take Over. Advertising Age, 61(41), 26.

Lawrence, E., Corbitt, B, Fisher, J.A, Lawrence, J. \& Tidwell, A. (2000). Internet Commerce (2nd ed.). John Wiley \& Sons Australia Ltd, 79.

Lazer, W. \& Kelly, E. K. (1962). Managerial Marketing: Perspectives and Viewpoints. IL: Richard D. Irwin.

Lazer, W., Culley, J.D. \& Staudt, T. (1973). The Concept of the Marketing Mix, In Britt, S. H. (Ed.), Marketing Manager's Handbook. Chicago: The Dartnell Corporation, 39-43.

Low, S. P. \& Kok, H. M. (1997). Formulating A Strategic Marketing Mix for Quantity Surveyors. Marketing Intelligence \& Planning, 15(6), 273-280.

Low, S. P. \& Tan, M. C. S. (1995). A Convergence of Western Marketing Mix Concepts and Oriental Strategic Thinking. Marketing Intelligence \& Planning, 13(2), 36-46.

MaGrath A. J. (1986). When Marketing Services, 4Ps Are Not Enough. Business Horizons, 29(3), 45-50.

McCarthy, E. J. (1960). Basic Marketing, A ManagerialAapproach. IL: Richard D. Irwin.

McCarthy, E. J. (1964). Basic Marketing, IL: Richard D. Irwin.

McDaniel, S. W. and Hise, R. T. (1984). Shaping the Marketing Curriculum: The CEO Perspective. Journal of Marketing Education, Summer, 27-32.

Melewar, T. C. \& Saunders, J. (2000). Global Corporate Visual Identity Systems: Using an Extended Marketing Mix. 
European Journal of Marketing, 34(5/6), 538-550.

Mickwitz, G.. (1959). Marketing and Competition. Finland: Societas Scientarium Fennica, Helsingfors.

Möller, K. (2006). The Marketing Mix Revisited: Towards the 21st Century Marketing by E. Constantinides. Journal of Marketing Management, 22(3), 439-450.

Mosley-Matchett, J. D. (1997). Include the Internet in Marketing Mix. Marketing News, 31(25).

Mulhern, F. J. (1997). Retail Marketing: From Distribution to Integration. International Journal of Research in Marketing, 14(2), 103-124.

NetMBA (n.d). The Marketing Mix (The 4 P's of Marketing). [Online] Available: http://www.netmba.com/marketing/mix.

NetMBA (n.d). The Marketing Mix (The 4 P's of Marketing). [Online] Available: http://www.netmba.com/marketing/mix.

O'Connor, J. \& Galvin, E. (1997). Marketing and Information Technology - The strategy, Application and Implementation of IT in Marketing. London: Pitman Publishing.

Ohmae, K. (1982). The Mind of the Strategist: The Art of Japanese Business. New York: McGrow-Hill Inc.

Palmer, A. (2004). Introduction to Marketing - Theory and Practice, UK: Oxford University Press.

Parasuraman, A. (1998). Customer Service in Business-to-Business Markets: An Agenda for Research. The Journal of Business and Industrial Marketing, 13(4), 309-321.

Patterson, G.P. \& Ward, T. (2000). Relationship Marketing and Management, Handbook Services Marketing and Management. Sage Publications Inc, 416.

Peattie, K. (1997). The Marketing Mix in the Third Age of Computing. Marketing Intelligence \& Planning, 15(3), 142-150.

Perreault, W. D. Jr. \& Russ, F. A. (1976). Physical Distribution Service in Industrial Purchase Decisions. Journal of Marketing, 40(4), 3-10.

Popovic, D. (2006). Modelling the Marketing of High-Tech Start-Ups. Journal of Targeting, Measurement and Analysis for Marketing, 14(3), 260-276.

Rafiq, M. \& Ahmed, P. K. (1995). Using the 7Ps as A Generic Marketing Mix: An Exploratory Survey of UK and European Marketing Academics. Marketing Intelligence \& Planning, 13(9), 4-15.

Rasmussen, A. (1955). Pristeori Eller Parameterteori - Studier Omkring Virksomhedens Afsaetning (Price Theory or Parameter Theory - Studies of the Sales of the Firm. Denmark: Erhvervsokonomisk Forlag.

Robicheaux, R. A. (1976). How Important Is Pricing in Competitive Strategy?. In Nash, H. W \& Donald, P. R. (Eds). Southern Marketing Association 1975 Conference, Southern Marketing Association, Atlanta, 55-57.

Robins, F. (1991). Four Ps or Four Cs or Four Ps and Four Cs. Paper Presented at MEG Conference.

Rosenberg, L. \& Czepiel, J. (1992). A Marketing Approach to Consumer Retention. Journal of Consumer Marketing, 59, $58-70$.

Rousey, S. P. \& Morganosky, M. A. (1996). Retail Format Change in US Markets. International Journal of Retail \& Distribution Management, 24(3), 8-16.

Rushton, A. \& Carson, D. J. (1989). Services - Marketing With A Difference?. Marketing Intelligence and Planning, $7(5 / 6), 12-17$.

Schultz, D. E. (2001). Marketers: Bid Farewell To Strategy Based on Old 4Ps. Marketing News, 35(2), 7.

Ster, V. D. W. (1993). Marketing En Detailhandel (Marketing and Retailing). The Netherlands: Groningen, Wolters-Noordhoff, 328.

Turnbull P., Ford, D. \& Cunningham, M. (1996). Interaction, Relationships and Networks in Business Markets: An Evolving Perspective. Journal of Business \& Industrial Marketing, 11(3/4), 44-62.

Udell, J.G. (1964). How Important Is Pricing in Competitive Strategy. Journal of Marketing, 28, 44-48.

Udell, J.G. (1968). The Perceived Importance of the Elements of Strategy. Journal of Marketing, 32, 34-40.

Van Waterschoot, W. (n.d). Chapter 9: The Marketing Mix as a Creator of Differentiation, Blois: The Oxford Textbook of Marketing, Instructor's Manual, Oxford University Press. [Online] Available: http://www.oup.com/uk/orc/bin/9780198775768/freelecturer/manual/imchap09.pdf.

Vignali, C. \& Davies, B. J. (1994). The Marketing Mix Redefined and Mapped - Introducing the MIXMAP Model. 
Management Decision, 32(8), 11-16.

Von Stackelberg, H. (1939). Theorie Der Vertriebspolitik und Der Qualitatsvariation. Smollers Jahrbuch, 63(1).

Wang, F., Head, M. \& Archer, N. (2000). A Relationship-Building Model for The Web Retail Marketplace. Internet Research: Electronic Networking Applications and Policy, 10(5), 374-384.

Wang, K. L., Wang, Y. \& Yao, J. T. (2005). A Comparative Study on Marketing Mix Models for Digital Products. Proceedings of the First International Workshop on Internet and Network Economics (WINE'05), Hong Kong, China, December 15-17, 660-669.

Wu, C. C. \& Wu, S. I. (1998). A Proposed Method for the Development of Marketing Mix of the Tea Drink Market. Asia Pacific Journal of Marketing and Logistics, 10(1), 3-21.

Yudelson, J. (1999). Adapting McCarthy's Four P's for the Twenty-First Century. Journal of Marketing Education, 21(1), 60 .

Table 1. Review of consumer marketing theory literature

\begin{tabular}{|c|c|c|}
\hline Author & Arguments & Proposition \\
\hline Kotler (1984) & $\begin{array}{l}\text { External and uncontrollable environmental factors } \\
\text { are very important elements of the marketing } \\
\text { strategy Programs. }\end{array}$ & $\begin{array}{l}\text { The Marketing Mix should include } \\
\text { customers, environmental variables, and } \\
\text { competitive variables. } \\
\text { Two additional Ps to the } 4 \text { traditional ones: } \\
\text { Political power, and public opinion } \\
\text { formulation. }\end{array}$ \\
\hline Ohmae (1982) & $\begin{array}{l}\text { No strategic elements are to be found in the } \\
\text { marketing mix. The marketing strategy is defined by } \\
\text { three factors. }\end{array}$ & $\begin{array}{l}\text { Three Cs define and shape the marketing } \\
\text { strategy: Customers, competitors, and } \\
\text { corporation. }\end{array}$ \\
\hline Robins (1991) & $\begin{array}{l}\text { The 4Ps Marketing Mix is too much internally } \\
\text { oriented. }\end{array}$ & $\begin{array}{l}\text { Four Cs expressing the external orientation } \\
\text { of a Marketing Mix: Customers, } \\
\text { competitors, capabilities, and company. }\end{array}$ \\
\hline $\begin{array}{l}\text { Vignalli and } \\
\text { Davies (1994) }\end{array}$ & $\begin{array}{l}\text { Marketing planning will contribute to the } \\
\text { organisational success if it is closely related to } \\
\text { strategy. The Marketing Mix is limited to internal } \\
\text { and non-strategic issues. }\end{array}$ & $\begin{array}{l}\text { The MIXMAP technique allows the exact } \\
\text { mapping of marketing mix elements and } \\
\text { variables, allowing the consistency between } \\
\text { strategy and tactics. }\end{array}$ \\
\hline Doyle (1994) & $\begin{array}{l}\text { While the } 4 \text { Ps dominate the marketing Management } \\
\text { activities most marketing practitioners would add } \\
\text { two more elements in this mix in order to position } \\
\text { their products and achieve the marketing objectives. }\end{array}$ & $\begin{array}{l}\text { Two more factors must be added to the } 4 \mathrm{P} \\
\text { mix: Services, and staff. }\end{array}$ \\
\hline Bennett (1997) & $\begin{array}{l}\text { Focused on internal variables therefore incomplete } \\
\text { basis for marketing. Customers are disposed to buy } \\
\text { products from the opposite direction to that } \\
\text { suggested by the Marketing Mix }\end{array}$ & $\begin{array}{l}\text { Five Vs are the criteria of customer } \\
\text { disposition: Value, viability, variety, volume, } \\
\text { and virtue. }\end{array}$ \\
\hline $\begin{array}{c}\text { Yudelson } \\
1999\end{array}$ & $\begin{array}{l}\text { The } 4 \text { Ps are not the proper basis of the } 21^{\text {st }} \text { century } \\
\text { marketing. The Marketing developments of the last } \\
40 \text { years require a new flexible Platform while the } \\
\text { simplicity of the old model remains an attractive } \\
\text { facto. }\end{array}$ & $\begin{array}{l}4 \text { new Ps based on exchange activities: } \\
\text { Product } \rightarrow \text { Performance } \\
\text { Price } \rightarrow \text { Penalty } \\
\text { Promotion } \rightarrow \text { Perceptions } \\
\text { Place } \rightarrow \text { Process }\end{array}$ \\
\hline $\begin{array}{c}\text { Schultz } \\
2001\end{array}$ & $\begin{array}{l}\text { Marketplaces today are customer oriented. The 4Ps } \\
\text { have less relevance today, they made sense the time } \\
\text { they were invented }\end{array}$ & $\begin{array}{l}\text { End-consumer controls the market } \\
\text { Network systems should define the } \\
\text { orientation of a new Marketing } \\
\text { A new Marketing mix must be based on the } \\
\text { Marketing Triad Marketer, Employee and } \\
\text { Customer }\end{array}$ \\
\hline
\end{tabular}


Table 2. Review of relationship marketing literature

\begin{tabular}{|c|c|c|}
\hline Author & Arguments & Proposition \\
\hline $\begin{array}{c}\text { Lauterborm } \\
\text { (1990) }\end{array}$ & $\begin{array}{l}\text { The 4PsMarketing Mix is product oriented } \\
\text { The successful marketing plan must place the } \\
\text { customer in the centre of the marketing planning }\end{array}$ & $\begin{array}{l}\text { Four Cs replace the } 4 \mathrm{Ps} \text {, indicating the } \\
\text { customer orientation: Customer needs, } \\
\text { convenience, cost (customer's), and } \\
\text { communication. }\end{array}$ \\
\hline $\begin{array}{l}\text { Rozenberg and } \\
\text { Czepiel (1992) }\end{array}$ & $\begin{array}{l}\text { Keeping existing customers is as important as } \\
\text { acquiring new ones. The approach towards existing } \\
\text { customers must be active, based on a separate } \\
\text { marketing mix for customer retention. }\end{array}$ & $\begin{array}{l}\text { Retention Marketing Mix: Product extras, } \\
\text { reinforcing promotions, sales-force } \\
\text { connections, specialised distribution, and } \\
\text { post-purchase communication }\end{array}$ \\
\hline $\begin{array}{l}\text { Gummesson } \\
(1994,1997)\end{array}$ & $\begin{array}{l}\text {.."The role of the } 4 \mathrm{Ps} \text { is changing from being } \\
\text { founding Parameters of Marketing to one of being } \\
\text { contributing parameters to relationships, network } \\
\text { and interaction"... }\end{array}$ & $\begin{array}{l}30 \mathrm{R} \text { (elationship) parameters illustrate the } \\
\text { role of marketing as a mix of relationships, } \\
\text { networks and interaction. }\end{array}$ \\
\hline Grönroos (1994) & $\begin{array}{l}\text { Several arguments underlying the limitations of the } \\
\text { marketing mix as the Marketing paradigm: } \\
\text { Obsolete, not integrative, based on conditions not } \\
\text { common to all markets, production oriented, not } \\
\text { interactive etc. }\end{array}$ & $\begin{array}{l}\text { Relationship marketing offers all the } \\
\text { necessary ingredients to become the new } \\
\text { Marketing Paradigm, while the Marketing } \\
\text { Mix is not suitable to support a } \\
\text { relation-based approach. }\end{array}$ \\
\hline Goldsmith (1999) & $\begin{array}{l}\text { The trend towards personalisation has resulted in an } \\
\text { increasing contribution of services to the marketing } \\
\text { of products. Personalisation must become the basis } \\
\text { of the marketing management trajectory. }\end{array}$ & $\begin{array}{l}\text { The personalised Marketing Plan includes } 4 \\
\text { more P's next to the traditional Ps of the } \\
\text { Marketing Mix } \\
\text { - Personalisation } \\
\text { - Personnel } \\
\text { - Physical Assets } \\
\text { - Procedures }\end{array}$ \\
\hline $\begin{array}{l}\text { Patterson and } \\
\text { Ward (2000) }\end{array}$ & $\begin{array}{l}\text { The traditional Marketing Mix therefore has a } \\
\text { clearly offensive character because the strategies } \\
\text { associated to the 4Ps tend to be function-oriented and } \\
\text { output oriented. } \\
\text { Well-managed organisations must shift the emphasis } \\
\text { in managing valued customer relationships in order } \\
\text { to retain and increase their customer base. }\end{array}$ & $\begin{array}{l}\text { Four information-intensive strategies form } \\
\text { the "new Cs" of Marketing: } \\
\text { - Communication } \\
\text { - Customisation } \\
\text { - Collaboration } \\
\text { - - Clairvoyance }\end{array}$ \\
\hline $\begin{array}{l}\text { Healy et al. } \\
\text { (2001) }\end{array}$ & $\begin{array}{l}\text { The weight of Marketing Management is clearly } \\
\text { switching towards relationship marketing as the } \\
\text { future marketing paradigm }\end{array}$ & $\begin{array}{l}\text { The Relationship Marketing addresses the } \\
\text { elements of Marketing Management } \\
\text { identified by the Marketing Relationship } \\
\text { trilogy: } \\
\text { - Relationships } \\
\text { - Neo-Relationship Marketing } \\
\text { - Networks }\end{array}$ \\
\hline
\end{tabular}

Adapted from: Möller (2006) 
Table 3. Review of services marketing literature

\begin{tabular}{|c|c|c|}
\hline Author & Arguments & Proposition \\
\hline $\begin{array}{l}\text { Booms and } \\
\text { Bitner (1981) }\end{array}$ & $\begin{array}{l}\text { Recognising the special character of the services as products, } \\
\text { they demonstrated the importance of Environmental factors } \\
\text { (Physical Evidence) influencing the quality perception. They } \\
\text { included the Participants (personnel and customers) and the } \\
\text { Process of service delivery as the additional Marketing Mix } \\
\text { factors. }\end{array}$ & $\begin{array}{l}\text { The Services Marketing Mix includes } \\
\text { next to the 4Ps three more P's: } \\
\text { - Participants } \\
\text { - Physical Evidence } \\
\text { - Process }\end{array}$ \\
\hline $\begin{array}{l}\text { Cowell } \\
(1984)\end{array}$ & $\begin{array}{l}\text { Three aspects justifying the revision of the original } \\
\text { Marketing mix framework: } \\
\text { - the original mix was developed for manufacturing } \\
\text { companies } \\
\text { - empirical evidence suggesting that marketing } \\
\text { practitioners in the service sector find the marketing } \\
\text { mix not being inclusive enough for their needs }\end{array}$ & $\begin{array}{l}\text { Adopts the framework proposed by } \\
\text { Booms and Bitner }\end{array}$ \\
\hline $\begin{array}{l}\text { Brunner } \\
(1989)\end{array}$ & $\begin{array}{l}\text { The 4P Marketing mix elements must be extended to include } \\
\text { more factors affecting the services marketing thus becoming } \\
\text { mixes themselves }\end{array}$ & $\begin{array}{l}\text { Concept Mix, Cost Mix, Channels Mix, } \\
\text { Communication Mix }\end{array}$ \\
\hline $\begin{array}{l}\text { Ruston and } \\
\text { Carson } \\
(1989)\end{array}$ & $\begin{array}{l}\text { The unique characteristics of the services - intangibility, } \\
\text { inseparability, perishability and variability - make the } \\
\text { control of the marketing process, using the generalised tools } \\
\text { of marketing, inadequate }\end{array}$ & $\begin{array}{l}\text { New instruments and concepts must be } \\
\text { developed to explain and manage the } \\
\text { services intangibility }\end{array}$ \\
\hline Fryar (1991) & $\begin{array}{l}\text { Segmentation and differentiation is the basis of successful } \\
\text { positioning of services. Furthermore the personal } \\
\text { relationship with the customer and the quality of the service } \\
\text { are important elements of the services Marketing }\end{array}$ & $\begin{array}{l}\text { The Marketing of services requires: } \\
\text { - Differentiation based } \\
\text { segmentation and positioning } \\
\text { - Customer contact } \\
\text { - Unique vision on quality }\end{array}$ \\
\hline $\begin{array}{c}\text { Heuvel } \\
(1993)\end{array}$ & $\begin{array}{l}\text { Interaction between the one delivering the service and the } \\
\text { customer is very important and has direct effect on the } \\
\text { service quality and quality perception. The Product element } \\
\text { can be better demonstrated as having two components, the } \\
\text { primary and secondary service elements as well as the } \\
\text { process }\end{array}$ & $\begin{array}{l}\text { The Services Marketing Mix: } \\
\text { - Personnel } \\
\text { - Product } \\
\text { - Place } \\
\text { - Price } \\
\text { - Promotion }\end{array}$ \\
\hline Doyle (1994) & $\begin{array}{l}\text { While recognising that the content of the } 4 \text { Ps in the service } \\
\text { sector is somehow different from that of the tangibles he } \\
\text { does accept the 4Ps as the elements of the services marketing } \\
\text { mix. He identifies special difficulties in Promotion and Place } \\
\text { preferring to replace them by the terms Communication and } \\
\text { Distribution }\end{array}$ & $\begin{array}{l}\text { Service Marketing Mix: } \\
\text { - } \quad \text { Product } \\
\text { - } \quad \text { Price } \\
\text { - } \quad \text { Communication } \\
\text { - } \quad \text { Distribution }\end{array}$ \\
\hline
\end{tabular}


Table 4. Review of Services Marketing Literature (continued)

\begin{tabular}{|c|l|l|}
\hline Author & \multicolumn{1}{|c|}{ Arguments } & \multicolumn{1}{|c|}{ Proposition } \\
\hline $\begin{array}{c}\text { Melewar and } \\
\text { Saunders } \\
(2000)\end{array}$ & $\begin{array}{l}\text { The Corporate Visual Identity System (CVIS) is the basis of } \\
\text { the corporate differentiation and the core of the company's } \\
\text { visual identity. }\end{array}$ & $\begin{array}{l}\text { A new P must be added to the 4Ps of the } \\
\text { Marketing Mix (and the 3Ps of the } \\
\text { Services Mix) namely the Publications }\end{array}$ \\
\hline $\begin{array}{c}\text { English } \\
(2000)\end{array}$ & $\begin{array}{l}\text { The traditional Marketing has never been an effective tool for } \\
\text { health services marketing }\end{array}$ & $\begin{array}{l}\text { A new framework emerges, } \\
\text { emphasising the 4 Rs Relevance, } \\
\text { Response, Relationships, and Results. }\end{array}$ \\
\hline $\begin{array}{c}\text { Grove et al. } \\
(2000)\end{array}$ & $\begin{array}{l}\text { Services Marketing can be compared to a theatrical } \\
\text { production. How the service is performed is as important as } \\
\text { what is performed. Critical factor is therefore the customer } \\
\text { experience. The traditional Marketing Mix does not } \\
\text { adequately capture the special circumstances that are present } \\
\text { when marketing a service product }\end{array}$ & $\begin{array}{l}\text { Four strategic theatrical elements } \\
\text { constitute the Services Experience: } \\
\text { Actors, Audience, Setting, and } \\
\text { Performance } \\
\text { These elements must be added to the } \\
\text { extended services Marketing Mix model } \\
\text { of Booms en Bitner }\end{array}$ \\
\hline $\begin{array}{c}\text { Beckwith } \\
(2001)\end{array}$ & $\begin{array}{l}\text { Marketing services in a changing world requires focusing on } \\
\text { increasing the customer satisfaction and rejecting old product } \\
\text { paradigms and marketing fallacies. }\end{array}$ & $\begin{array}{l}\text { The four keys of Modern (services) } \\
\text { Marketing: Price, Brand, Packaging, } \\
\text { and Relationships }\end{array}$ \\
\hline
\end{tabular}

Adapted from: Möller (2006) 
Table 5. Review of retail marketing literature

\begin{tabular}{|c|c|c|}
\hline Author & Arguments & Proposition \\
\hline $\begin{array}{l}\text { Ster van der } \\
\text { (1993) }\end{array}$ & $\begin{array}{l}\text { The retail format is the focus of retail marketing, the } \\
\text { basis of merchant differentiation and the element that } \\
\text { attracts potential customers in the retail outlet. } \\
\text { The Marketing Mix for retailers is divided into two } \\
\text { groups of factors the logistical and commercial ones }\end{array}$ & $\begin{array}{l}\text { The Retailing Marketing Mix: } \\
\text { - } \quad \text { Logistics Concept: Place mix, physical } \\
\text { distribution mix, and personnel mix } \\
\text { - } \quad \text { Commercial Concept: Product mix, } \\
\text { presentation mix, price mix, and } \\
\text { promotion mix }\end{array}$ \\
\hline $\begin{array}{l}\text { Boekema et al. } \\
\text { (1995) }\end{array}$ & $\begin{array}{l}\text { The consumer choice for a retail outlet depends on } \\
\text { the "Shop Picture" the customer develops. The } \\
\text { retailers can use the Marketing mix instruments in } \\
\text { order to give form to their retail format (retail } \\
\text { formula) which addresses the consumer's } \\
\text { expectations and influences his/her choice }\end{array}$ & $\begin{array}{l}\text { The Retailing Marketing Mix: } \\
\text { - } \quad \text { Place } \\
\text { - } \quad \text { Assortment } \\
\text { - } \quad \text { Shop Presentation } \\
\text { - } \quad \text { Price Policy } \\
\text { - } \quad \text { Personnel } \\
\text { - } \quad \text { Promotion }\end{array}$ \\
\hline $\begin{array}{l}\text { Rousey and } \\
\text { Morganosky } \\
\quad(1996)\end{array}$ & $\begin{array}{l}\text { Empirical evidence suggests that the retail formats } \\
\text { rather that the individual elements of the Marketing } \\
\text { Mix are the building blocks of customer value. }\end{array}$ & $\begin{array}{l}\text { Retailing marketers should replace the } 4 \mathrm{Ps} \\
\text { with the Lauterborn's } 4 \text { C's: Customer needs, } \\
\text { convenience, cost (customer's), and } \\
\text { communication }\end{array}$ \\
\hline Mulhern (1997) & $\begin{array}{l}\text { Modern retailing is increasingly based on a shift } \\
\text { from traditional merchandising that usually places } \\
\text { attention to marketing mix elements, towards active } \\
\text { customer management by means of an integrated } \\
\text { approach to retailing. More emphasis to customer } \\
\text { relationships, rewarding regular customers and close } \\
\text { cooperation with manufacturers }\end{array}$ & $\begin{array}{l}\text { Elements of the integrated Retailing Strategy } \\
\text { are: } \\
\text { - } \quad \text { Store location } \\
\text { - } \quad \text { Store positioning } \\
\text { - } \quad \text { Store image } \\
\text { - } \quad \text { Physical environment } \\
\text { - } \quad \text { Retail service }\end{array}$ \\
\hline $\begin{array}{l}\text { Wang et al. } \\
\text { (2000) }\end{array}$ & $\begin{array}{l}\text { While the 4Ps form the basis of the traditional } \\
\text { marketing, the task of marketers in relationship } \\
\text { marketing is different: The main tasks are } \\
\text { identifying, establishing, maintaining and enhancing } \\
\text { relationships (Grönroos 1996). }\end{array}$ & $\begin{array}{l}\text { The Basic components of Web retail are the } \\
\text { three basic components of relationship } \\
\text { marketing: } \\
\text { - } \quad \text { Database } \\
\text { - Interaction } \\
\text { - Network }\end{array}$ \\
\hline Kotler (2003) & $\begin{array}{l}\text { The customer sophistication has forced retailers to } \\
\text { review their strategies. Factors like procurement and } \\
\text { service have become basic elements of the retailer's } \\
\text { marketing mix }\end{array}$ & $\begin{array}{l}\text { Retailer's marketing Decisions: } \\
\text { - } \quad \text { Target Market } \\
\text { - } \quad \text { Product assortment and Procurement } \\
\text { - } \quad \text { Services and Store Atmosphere } \\
\text { - } \quad \text { Price Decision } \\
\text { - } \quad \text { Promotion decision } \\
\text { - } \quad \text { Place Decision }\end{array}$ \\
\hline
\end{tabular}

Adapted from: Möller (2006) 
Table 6. Review of industrial marketing literature

\begin{tabular}{|c|c|c|}
\hline Author & Arguments & Proposition \\
\hline $\begin{array}{l}\text { Turnbull et. al } \\
\qquad(1996)\end{array}$ & $\begin{array}{l}\text { More than } 20 \text { years of research by the } \\
\text { International Marketing and Purchasing Group } \\
\text { (IMP) indicate that success in Business to } \\
\text { Business Marketing is based on the degree and } \\
\text { the quality of the interdependence between firms }\end{array}$ & $\begin{array}{l}\text { Competitive advantage of firms engaged in B2B } \\
\text { marketing will depend on: Interaction with } \\
\text { customers, interaction strategies, organisation } \\
\text { evolution, improvements in customer portfolios, } \\
\text { inter-organisational - personal contacts, and } \\
\text { network mobilisation }\end{array}$ \\
\hline $\begin{array}{l}\text { Davis and Brush } \\
\text { (1997) }\end{array}$ & $\begin{array}{l}\text { The 4Ps Marketing Mix is not suitable as the } \\
\text { conceptual basis for the Marketing of the } \\
\text { High-tech Industry. This because: a. The 4Ps are } \\
\text { based on marketing of consumer products, b. } \\
\text { International elements are not taken into } \\
\text { consideration }\end{array}$ & $\begin{array}{l}13 \text { strategic elements form the marketing } \\
\text { platform of the Hightech industry }\end{array}$ \\
\hline $\begin{array}{l}\text { Parasuraman } \\
\quad(1998)\end{array}$ & $\begin{array}{l}\text { The key to value creation is assisting the } \\
\text { customer to achieve his own corporate objectives. }\end{array}$ & $\begin{array}{l}\text { The basis of Industrial Marketing is the } \\
\text { Personalised Approach with special emphasis } \\
\text { on: Customer service, teamwork, service quality, } \\
\text { and excellence }\end{array}$ \\
\hline $\begin{array}{l}\text { Andersen and } \\
\text { Narus (1999) }\end{array}$ & $\begin{array}{l}\text { The role of business marketing in a value-based } \\
\text { environment is the efficient management of } \\
\text { relationships and networks. }\end{array}$ & $\begin{array}{l}\text { Value-based positioning orients and updates each } \\
\text { of the four Ps }\end{array}$ \\
\hline Peattie (1997) & $\begin{array}{l}\text { The new communication and interaction } \\
\text { capabilities will change everything around } \\
\text { marketing in many industries, yet the basic } \\
\text { marketing concept will remain unchanged. New } \\
\text { role for the 4P's of the Marketing Mix. }\end{array}$ & $\begin{array}{l}\text { - Product: co-design and production } \\
\text { - Price: more transparency } \\
\text { - Place: direct contacts with customers } \\
\text { - Promotion: more control of the customer, } \\
\text { interaction }\end{array}$ \\
\hline $\begin{array}{l}\text { Aldridge et. al } \\
\quad(1997)\end{array}$ & $\begin{array}{l}\text { There are several and important differences } \\
\text { between the physical Marketing and the online } \\
\text { marketing. Many new factors define the } \\
\text { limitations of the traditional Marketing } \\
\text { Management }\end{array}$ & $\begin{array}{l}\text { While the 4P's can remain the backbone } \\
\text { activities of Ecommerce they acquire a new and } \\
\text { different role in the online marketplace. }\end{array}$ \\
\hline $\begin{array}{c}\text { Mosley- } \\
\text { Matchett (1997) }\end{array}$ & $\begin{array}{l}\text { A successful presence on the Internet is based on } \\
\text { a Web site designed on the basis of a Marketing } \\
\text { Mix of } 5 \text { W's }\end{array}$ & $\begin{array}{l}\text { Who: Target audience / market, What: Content, } \\
\text { When: Timing and updating, Where: Findability, } \\
\text { Why: Unique Selling Proposition }\end{array}$ \\
\hline $\begin{array}{l}\text { Evans and King } \\
\text { (1999) }\end{array}$ & $\begin{array}{l}\text { There are four steps in building a successful B2B } \\
\text { web site. Each of these steps brings with it a } \\
\text { number of major managerial implications. }\end{array}$ & $\begin{array}{l}\text { Web Planning: defining mission and goals, Web } \\
\text { Access: How to get Web entry, Site Design and } \\
\text { Implementation: Content, Site Promotion, } \\
\text { Management and Evaluation: Commercial and } \\
\text { managerial aspects }\end{array}$ \\
\hline
\end{tabular}


Table 7. Review of E-Commerce marketing literature

\begin{tabular}{|c|c|c|}
\hline Author & Arguments & Proposition \\
\hline $\begin{array}{c}\text { Chaffey et al. } \\
(2000)\end{array}$ & $\begin{array}{l}\text { Argues that the Internet can provide } \\
\text { opportunities to vary the elements of the } \\
\text { traditional marketing mix, while he identifies six } \\
\text { key elements for effective web site design: } \\
\text { Capture, Content, Community, Commerce, } \\
\text { Customer Orientation, Credibility. }\end{array}$ & $\begin{array}{l}\text { The Internet marketing planning is based on eight } \\
\text { critical factors: } \\
\text { - } \text { Potential Audience } \\
\text { - } \text { Integration } \\
\text { - } \text { Marketing Support } \\
\text { - } \text { Brand migration } \\
\text { - } \quad \text { Strategic Partnerships } \\
\text { - } \text { Organisational Structure } \\
\text { - } \text { Budget }\end{array}$ \\
\hline $\begin{array}{c}\text { Lawrence et al. } \\
(2000)\end{array}$ & $\begin{array}{l}\text { A hybrid approach suggesting that creating an } \\
\text { online marketing activity should be based on the } \\
\text { traditional Ps of the marketing mix (indeed with } \\
\text { two add-ons; people and packaging) as well as } \\
\text { the new five P's of Marketing }\end{array}$ & 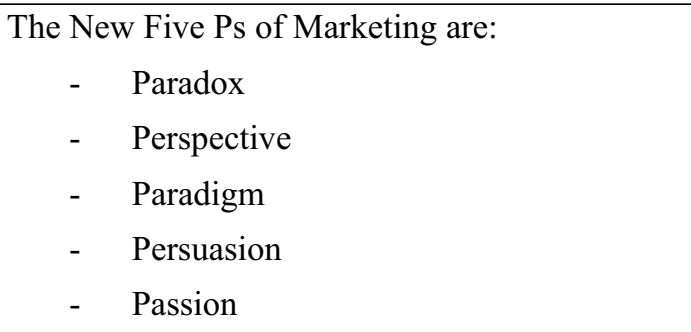 \\
\hline $\begin{array}{c}\text { Kambil and } \\
\text { Nunes (2000) }\end{array}$ & $\begin{array}{l}\text { Looking to the marketing of music products } \\
\text { E-Commerce Marketing requires new } \\
\text { approached from marketers, they have to move } \\
\text { away from the traditional approach based on the } \\
\text { 4P Marketing Mix }\end{array}$ & $\begin{array}{l}\text { Important elements of the online marketing: } \\
-\quad \text { Community building } \\
-\quad \text { Original event programming } \\
-\quad \text { Convenience } \\
-\quad \text { Connectivity }\end{array}$ \\
\hline $\begin{array}{l}\text { O'Connor and } \\
\text { Galvin (1997) }\end{array}$ & $\begin{array}{l}\text { While concluding that the marketing is finding } \\
\text { itself in a mid-life crisis they suggest that the } \\
\text { 4P's can remain the backbone of online } \\
\text { marketing they argue that technology can be } \\
\text { implemented in order to improve and optimise } \\
\text { the online, 4P-based marketing activities }\end{array}$ & $\begin{array}{l}\text { New technology-based functionality maintains } \\
\text { the 4P's as the basic planning tool for online } \\
\text { marketing }\end{array}$ \\
\hline $\begin{array}{l}\text { Bhatt and Emdad } \\
\text { (2001) }\end{array}$ & $\begin{array}{l}\text { The virtual value chain is changing the nature of } \\
\text { the 4P's and transforms them by adding new } \\
\text { dimensions. Businesses still make their strategic } \\
\text { marketing decisions based on the } 4 \mathrm{P} \text { Marketing } \\
\text { Mix. }\end{array}$ & $\begin{array}{l}\text { New Character of the 4P's } \\
\text { - } \quad \text { Product: new options for customised } \\
\text { information } \\
\text { - } \quad \text { Place: no time and location restrictions, } \\
\text { direct delivery } \\
\text { - } \quad \text { Price: price discrimination and } \\
\text { customisation, price transparency } \\
\text { - } \quad \text { Promotion: action-oriented promotional } \\
\text { activities are possible, promotional } \\
\text { flexibility }\end{array}$ \\
\hline
\end{tabular}


Table 8. Review of E-Commerce marketing literature (continued)

\begin{tabular}{|c|c|c|}
\hline Author & Arguments & Proposition \\
\hline Schultz (2001) & $\begin{array}{l}\text { Marketplaces today are customer oriented. } \\
\text { The 4P's have less relevance today; they } \\
\text { made sense the time they were invented. } \\
\text { Succeeding in the } 21^{\text {st }} \text { century interactive } \\
\text { marketplace means that marketing has to } \\
\text { move from an internal orientation } \\
\text { illustrated by the } 4 \text { Ps to a view of the } \\
\text { network or system }\end{array}$ & $\begin{array}{l}\text { - } \text { End-consumer controls the market } \\
\text { - Network systems should define the orientation } \\
\text { of a new Marketing } \\
\text { - A new Marketing mix must be based on the } \\
\text { Marketing Triad Marketer, Employee and } \\
\text { customer }\end{array}$ \\
\hline $\begin{array}{c}\text { Allen and } \\
\text { Fjermestad } \\
(2001)\end{array}$ & $\begin{array}{l}\text { Accept that the traditional } 4 \mathrm{P} \text { marketing } \\
\text { Mix can be the basis of the E-Commerce } \\
\text { strategy and identify the changes that are } \\
\text { needed to make the model suitable for } \\
\text { e-marketing }\end{array}$ & $\begin{array}{l}\text { 4P's major changes in an Ecommerce situation } \\
\text { - } \quad \text { Product: information, innovation } \\
\text { - } \quad \text { Place: Reach } \\
\text { - } \quad \text { Price: Increased competition } \\
\text { - } \quad \text { Promotion: More information, direct links }\end{array}$ \\
\hline $\begin{array}{c}\text { Constantinides } \\
\text { (2002) }\end{array}$ & $\begin{array}{l}\text { Some major flaws of the 4Ps mix as basis of } \\
\text { online marketing activities: Lack of } \\
\text { interactivity, lack of strategic elements in a } \\
\text { constantly developing environment, the 4Ps } \\
\text { are not the critical elements of online } \\
\text { marketing }\end{array}$ & $\begin{array}{l}\text { The } 4 \mathrm{~S} \text { model offers a comprehensive, integral } \\
\text { approach on managing the online presence: } \\
\text { - Scope: Strategic issues } \\
\text { - Site: Operational issues } \\
\text { - Synergy: Organisational issues } \\
\text { - System: Technological issues }\end{array}$ \\
\hline
\end{tabular}

Adapted from: Möller (2006)

Table 9. Strengths and weakness of the 4Ps and 7Ps

\begin{tabular}{|c|c|c|}
\hline & $7 \mathrm{Ps}$ & 4Ps \\
\hline Strengths & $\begin{array}{l}\text { More comprehensive } \\
\text { More detailed } \\
\text { More refined } \\
\text { Broader perspective } \\
\text { Includes participants/ } \\
\text { people and process } \\
\text { It is a model } \\
\text { Standardisation } \\
\text { Signals marketing theory }\end{array}$ & $\begin{array}{l}\text { Simplicity and ease of understanding } \\
\text { Easy to memorise } \\
\text { Good pedagogic tool, especially for introductory marketing } \\
\text { Parsimony } \\
\text { Useful conceptual framework } \\
\text { Ability to adapt to various problems }\end{array}$ \\
\hline Weaknesses & $\begin{array}{l}\text { More complicated } \\
\text { Extra elements can be } \\
\text { incorporated in 4Ps } \\
\text { Controllability of the three new } \\
\text { elements }\end{array}$ & $\begin{array}{l}\text { Too simple, not broad enough } \\
\text { Lacking people, participants and process } \\
\text { Physical evidence } \\
\text { Relationship marketing } \\
\text { Service } \\
\text { Lack of connection/integration between variables } \\
\text { Static nature of 4Ps }\end{array}$ \\
\hline
\end{tabular}

Adapted from: Rafiq and Ahmed (1995) 